SHS Web of Conferences 23, 04001 (2016)

DOI: $10.1051 /$ shsconf $/ 20162304001$

(C) Owned by the authors, published by EDP Sciences, 2016

\title{
THE SIGNIFICANT OF MODEL SCHOOL IN PLURALISTIC SOCIETY OFTHE THREE SOUTHERN BORDER PROVINCES OF THAILAND
}

\author{
Faisol Haji-Awang, Ph.D. \\ Faculty of Humanities and Social Sciences, \\ Prince of Songkla University, Pattani \\ Email : faiso1522@gmail.com
}

\begin{abstract}
This educational research is about the study of the schools' system in the Pluralistic Society of the Three Southern Border Provinces of Thailand. The research was carried out with some certain objectives in terms of analyzing the achievement of the Thai government schools in conducting the complete integrated Islamic studies programs from at least 12 experienced schools under the supervision of the Office of Regional Education of Pattani, Yala and Narathiwat Provinces. The analysis will be touched on the main issues such as the background of Islamic educational system, the current appropriate administrative structural system of the schools, the process of teaching and learning through the Islamic integrated method, communities' satisfaction in running the complete Islamic Studies program as well as the communities' reaction to this program. There are totally 12 schools are involved in this study : 6 of them from the Office of Regional Education of Pattani, 3 schools from the Office of Regional Education of Yala and another 3 schools from the Office of Regional Education of Narathiwat Province. This research employs a non-manipulative Multi-model Approach in collecting data from various kinds of figure such as officers from the Office of Regional Education; schools' administrators; Islamic studies teachers; students as well as communities near-by the schools. There are 108 sampling were participated in certain activities such as focus-group, dept-interview and discussion as well. Beside those methods, participation and observation were also used for. To evaluate and analyze the achievement of the schools' administrative procedure and the process of teaching and learning, however, this research depends on the Deming Cycle theory (PDCA), the Community's Participation framework as well as the Integrated Curriculum theory.
\end{abstract}

The result of the study show that, a significant traits of the model schools in the multicultural society are not merely performed well in administrative procedure, teaching and learning process, but these schools also able to reveal the real social norm and religious believe into communities' practical life as a truly "Malay-Muslim" society. It is means that, the school able to run the integrated programs under the shade of philosophy of Islamic education paralleled the National Education aims to ensure that the productivities of the programs able to serve both sides, national education on the one hand and the Malay Muslim communities' satisfaction on the other hand. 


\section{INTRODUCTION}

Since 2010, Minister of Education of Thailand has stipulated some crucial mile-stone of national education. These policies have been formulated to push forward a second decade of education reform. Emphasis is given to the provision of quality education and manpower development as the key to national development and enhanced competitiveness. Thailand aims to provide quality, student-centered, life-long learning opportunities. Clear indicators will be used to evaluate the performance of both teachers and learners. Focus at the Five Educational Levels: Pre-elementary, the 0-5 age group is seen as an important priority since the first five years of life are critical for brain development as well as to the overall physical, emotional and social health of the child; Primary, in addition to ensuring achievement of basic literacy and numeracy, primary level education will emphasize the acquisition of morals and values to instill a sense of Thainess, build respect for Thailand's rich cultural heritage and promote unity and social cohesiveness; Secondary and high-school levels, competency in foreign languages and computer literacy will be given high priority as they are among the basic skills required by the 21 st century learner. Emphasis will also be given to the promotion of morals and ethics leading to good citizenship. (The Bureau of International Cooperation Office of the Permanent Secretary, MOE, 2010)

Meanwhile, according to Islamic philosophy of education, seeking knowledge is compulsory for every Muslims (The meaning of al-Hadith [the tradition of the Prophet of Islam]). Base on al-Hadith mentioned, the prophet of Islam never mentioned knowledge to be divided into religious and secular. Therefore, the later Muslim scholars try to classify knowledge in terms of the needs of individual and communities instead of religious or secular. In fact, knowledge should be categorized into two traits; the first one regarding the knowledge which every Muslims have to know (fardu 'ain) in order to achieve any specific 'ibadat (religious obligatory) according to syari'at order, and the second related to any necessary branches of knowledge that pertain to life in this world (fardu kifayah) (Al-Ghazali 1872, 100). According to statements above, "integration" should not be a new concept in Islamic education that Muslims in anywhere and at anytime usually implement into their education system.

Therefore, in the multi-cultural society of the southern border provinces of Thailand, it seems that Malay Muslims have their own way in shaping education system. Although, Islamic educational institutions are reveled as the traditional institution which taught only Islamic religious knowledge to the community, but in practical, besides serving as the crucial educational institution for the Malays Muslim, history addressed that Islamic schools maintain some other significant role and function related to their identity and ethnicity. (Liow 2004, 2). ${ }^{1}$

Thus, this study tries to unfold the significant of model schools in the conflict area of three southern border provinces of Thailand which are dominated by Malay Muslim community. The focus of the discussion will be touched on the government policies on Islamic education system, the new trends of Islamic study and its curriculum. It is also

\footnotetext{
${ }^{1}$ See also Jane's Intelligence Review, vol. 16, no. 8, 11, November 2004; Western Resistance, July 2006 "Thailand: Death Toll Rises in Muslim South" Web access June 1, 2008 : www. westernresistance. com/blog/archives/002577 ; Isaac Kfir, 2007; AP Associated Press 2009. Web access : http://ap.mysinchew.com/node/25671
} 
will analyze the achievement of government in implementing the new Islamic education system resembling Pondok system (Islamic Private Educational Institution) into Thai government schools. The positive and negative responds from the Malay Muslims community to the new Islamic educational system implementing by government in terms of ethno-nationalist also will be elaborated.

To achieve all of the objectives stipulated, a certain method and approach had been used for this research. A non-manipulative Multi-model Approach was used in collecting data from various kinds of sources such as focus-group, dept-interview, discussion, participation, as well as observation. After cumulated all of the data required, this research try to use the Deming Cycle theory (PDCA) in order to analyze the achievement of implementing the full Islamic Studies Integrated programs. Thus, through what have been shown and reflected via the administrative procedure of the schools, the process of teaching and learning and the communities' participation, this research has come to the final conclusion as addressed below.

\section{THE SUSTAINING OF TRADITIONAL SYSTEM OF THE MALAY MUSLIM}

The process of institutional change has made the Muslim people of Pattani aware of the coming of the modern trend into their traditional institutions. To speak of modern trend, it makes the Muslim religious leaders wonder what is going to happen if such terms carry the meaning they seem to imply. Besides not being well-prepared in modern fields of education, traditional Muslims also know that Islamic education is totally different from what the secularists think education should be. (Madmarn 2000, 59)

In fact, an integrated curriculum is not a new concept for Muslim educators (Bhabha 1997). In the case of Islamic private schools in southern Thailand, however, their situation has a dilemma. Actually, Muslims in the southern border provinces are preparing themselves to face the new challenges from the government educational policy. Moreover, Muslims of Pattani and the areas nearby started to think about how to maintain their Islamic traditional heritage and at the same time regulate their situation in accordance with the national educational policy whose goal was an adequate education for modern life and for the integration of ethnic groups in the nation. Concerning this situation, Pitsuwan $(1982,78)$ identified this problem:

The entire population was now placed in a dilemma. If they wished to participate in the nation's political process, they would have to be educated in the government's secular schools. To take part in the educational system offered by the government would mean to cast off an important feature of their Malay Muslim ethnic and religious identity.

In adopting Islamic educational mainstream to be in line with the educational policy of the government, Muslim scholars in this region initially upgraded teaching-learning systems of Islamic private school into a systematic process that leads to changing the whole structure of the traditional Islamic institutions in all regions. In addition, in order to cope the traditional learning with the new challenging system, the young Muslim 
generations from the Islamic private school throughout the country are encouraged to choose their fields of study in both lines: that is to say, the academic and religious studies which is now a dilemma for them (Madmarn 2002, 83).

Recently, with the conviction that socio-economic development and the ending of violence will be assisted by strengthening education, the Ministry of Education has thus reviewed and redesigned the education policy for the southern border provinces. The Ministry is now working on improving the standard of education while promoting and preserving the educational arrangements of local communities, such as Tadika (training centers on moral and Islam at the mosque) and Pondok (Ministry of Education Thailand 2006). The main objectives are to provide education which is in response to the needs of local people and relevant to the economic, social and cultural circumstances, as well as to promote peaceful coexistence in these provinces (Thailand Knowledge Center 2009). The Ministry of Education in cooperation with "The Committee on the Southern Border Provinces Peace Building Policy" also has established "Centers of Coordination and Educational Management" in these provinces in order to integrate activities on educational development (Ministry of Foreign Affairs, Kingdom of Thailand 2006). All these were done in accordance to "The National Education Act" which stipulates that individuals, families, communities, and social and religious institutions including nongovernmental organizations have the right to basic education and are entitled to equitable benefits given by the government (Ministry of Education Thailand 2006).

Hence the major progress that has been made and measures being implemented in the year 2006 are as follows:

- Introducing bi-lingual instruction, namely, Thai and Jawi (local Malay dialect) in public primary schools in 12 pilot schools;

- Developing Thai, English, Chinese and Malay language teaching, including Jawi, as the media of instruction. Instruction media, including Thai-local Malay dictionaries, textbooks and CDs has been produced;

- Promoting teaching of Islam in 142 public schools and inviting reputable religious teacher (ustaz) to teach in these public schools;

- Improving academic qualification of personnel of private religious schools and Pondok by providing financial support to 103 administrators and 197 teachers to study educational management and social studies;

- Promoting cooperation between educational institutions and local communities in educational services by arranging workshops in 70 target schools;

- Supporting basic Islamic education on moral and Islam at 1,605 training centers at the mosque (TADIKA) by giving opportunities to local religious leaders and experts to participate in development of curriculum and textbooks. Training course on curriculum development had been arranged for 1,450 educational personnel, 3,440 religious teachers and 90 supervisors;

- Integrating general and vocational subjects into the syllabus of Islamic private schools and schools;

- Developing 54 Islamic private schools to be "Model Pondok" to serve as models for integrated teaching of secular and religious studies;

- Accelerating the process of establishing a Faculty of Islamic Studies at the Princess of Narathiwat University in Narathiwat Province, in cooperation with Syarif Hidayatullah State Islamic University of Indonesia (UIN Indonesia) and al-Azhar University of Egypt;

- Pursuing educational cooperation activities involving Thai Muslim students with neighboring countries such as Brunei Darussalam, Indonesia and Malaysia. 
- Granting scholarships to students in the southern provinces (Ministry of Education Thailand 2006).

Therefore, it might be attracted the attention of contemporary Malay Muslim scholars in terms of adopting a new approach for maintaining their identity and shaping future trends of historical Islamic educational system. However, there are still many questions regarding to the long run process of changing that Malay Muslim peoples in southern part of Thailand have to think seriously and answer accurately questions such as the following:

- What is the signification of the new Islamic education program?

- How the education reform act and new Islamic studies program affected Malay Muslim identity and Islamic religious school system?

- What are the new opportunities proposed through educational act and efforts in shaping future trends of the Islamic educational system and the Malay Muslim Identity?

- What should be the roles of the Malay Muslim scholars and religious leaders in meeting to the challenging of the new educational program?

- What are the responses of the Malay Muslim community upon education reform in terms of sustaining their authentic Islamic educational system?

Although all those questions probably no one able to give the answer accurately, but as Madmarn $(2009$, 59) explain that, to speak of modern trend in Islamic education, it makes the Muslim religious leaders always wonder what is going to happen if such terms carry the meaning they seem to imply. Indeed, the traditional Pondok remains central to Malay-Muslim identity and lifestyle in southern Thailand. Like other such institutions in Southeast Asia however, the Pondok of Thailand is confronted with the challenge of making themselves relevant in the context of social, political, and economic changes taking place in their environment (Liow 2004). In addition, recently there are more than 500 Pondok operating in southern Thailand, but only about 300 of them are registered with government authorities. It is no doubt that why Thai government suspects that some of these traditional Pondok are fostering religious extremism and harboring militants. About 30 of these 500 are suspected to be preaching violence in the name of Islam (Liow 2004, 2).

Since the January 2004 resurgence of violence in the south, government security forces have instituted regular searches of various Pondok, particularly in Pattani, Yala and Narathiwat. These incidences however, are increasingly undertaken without warning, and are viewed as violations of their religio-cultural space by the Muslim community (Jane's Intelligence Review, November 2004; Western Resistance, July 2006; Isaac Kfir 2007).

The government has also revived attempts to register theses traditional Pondok in order to regulate its education. Yet given the arbitrary way by which Pondok schools are created. This policy is proving increasingly difficult to implement. Moreover, many Pondok have gone underground for fear that registration will encourage further government incursion into Muslim education, and through that into Malay Muslim society. On the other hand, government funding to the Pondok system remains partly, a mere fraction of the budget allocation for southern provinces (Liow 2004, 2-3). 


\section{THE ACHIEVEMENTS OF THE IMPLEMENTATION OF THE COMPLETE ISLAMIC STUDIES PROGRAM IN GOVERNMENT SCHOOL}

It is important to be noted that, another action of changing the character of Islamic studies in southern border provinces of Thailand occurred when the Ministry of interior and Ministry of Education agreed to implement the new curriculum into government primary and secondary school under supervision of the Department of Local Administration. This program was fully operation on November 1, 2005. (Section of Educational Standard, Department of Local Administration 2005). It is obvious that the newest curriculum in both level of government school is not only general academic and tertiary education, but rather a complete combination of the secular and religious syllabuses.

Furthermore, the new Islamic studies program which is to be taught in government school, is not merely inadequate subjects of Islamic studies as used to be implemented before, but including all Islamic disciplines that are taught in Islamic private school, starting from Ibtida'i (primary Islamic syllabus) level and ending with Thanawi (secondary Islamic syllabus). This program means that students who successfully complete the entire curriculum stipulated by the course will obtain both academic and Islamic studies high school certificate together at the same time and able to extend their education at any university in the country and aboard. (Section of Educational Standard, Department of Local Administration 2005, 2-15)

After almost seven years of trailblazing, the best-practiced schools which have taken part in running this complete Islamic studies program have shown significant achievements in some crucial spheres such administrative structural system and appropriate syllabus and subject.

It is important to realize that this complete Islamic studies program undertaken by government schools are resembling Pondok system (Islamic Private School) which were an ideal model of Islamic education for Malay Muslim in this region. However, the previous administrative structural system of the government schools provided Head of Academic Affair that in-charged only for general curriculum. As a result, the bestpracticed school that running this program has to set a new administrative structural system that able to manage the complete Islamic integrated curriculum effectively. By adding the position of Community Board as a representative from Muslim religious leader such as Imam and Muslim scholars, they will act side by side with school director that actually know nothing about Islamic Studies.

\section{The Previous Administrative Structural System}

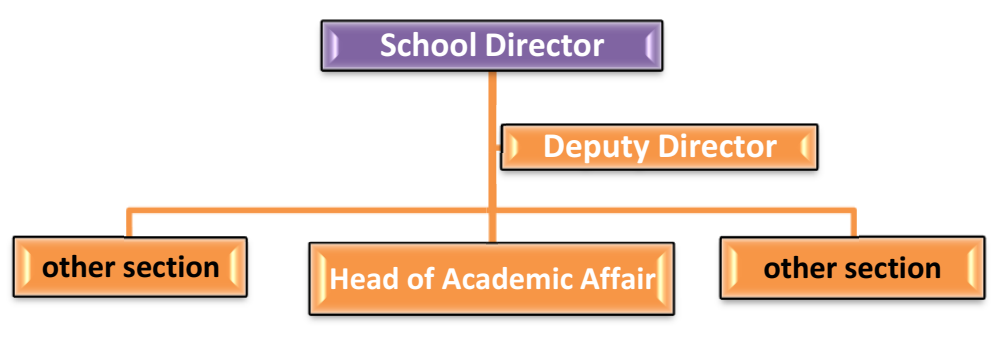


Another significant position that had been added was Head of Islamic Religious Knowledge (IRK), which able to act independently from Head of Academic Affaire as in the previous structure.

\section{The Current Administrative Structural System}

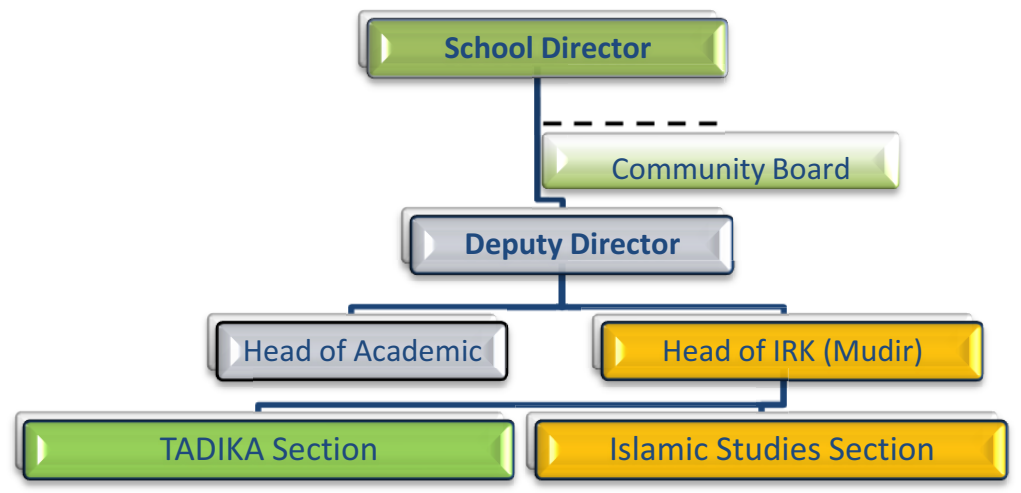

\section{RESULT OF THE STUDY}

As stipulated the main objectives of the study earlier, this educational research is about the study of the Educational System in the Pluralistic Society of the Three Southern Border Provinces of Thailand. The research was carried out with some certain objectives in terms of analyzing the best practice of the Thai government school in conducting the complete integrated Islamic studies program such as the administrative structural system; the process of teaching and learning throughout the Islamic integrated method as well as the obstacle and problem-solving from the experienced schools under the supervision of the Office of the Educational Region of Pattani, Yala and Narathiwat Provinces.

The result of the study implies with various degree of performances. For the administrative procedure of the school's directors in performing the main tasks such as planning, advertising and announcement the program, measuring and evaluating, reinforcement and treating Islamic studies teachers, overall are indicated with a good performance. However, by evaluating each indicator separately, it seems that the highest percentage of the performance of the school's directors was to appoint and form the committees to undertake the entire programs, and the lowest percentage of the performance was to evaluate the Islamic Studies teachers' teaching process.

Meanwhile, in the teaching and learning process, the result has shown that overall indicated in a very good performance. The teacher able to handle their work in a very good ability, start from basic task such as teaching preparation and end with evaluating the achievement of the students in every subjects completely.

For the Students' Desired Behaviors, according to the National Core Curriculum, the research has shown its result that, students able to achieve all Student's Key Performance Indicator (Students' KPI) perfectly. Thus, the main reason to explain the successful of the students' performance is that, because of the National Core Curriculum has mandated the Muslim students' KPI behaviors in accordance with a 
Muslims' Way of Life which they actually able to conduct as a normal routine in everyday life.

The result of the study of the Communities' Satisfaction of the Islamic Studies Program revealed that the parents, communities' leader and religious leaders almost indicated the satisfaction of feeling in running the Complete Integrated Islamic Studies Program in the Government schools. This is because the model schools had realized the reputations and the roles of the communities by appointing them in the schools' administrative structure, although it is appeared to be a non-formal duty.

However, the result of analyzing the process of teaching and learning has revealed that, almost teachers of the model schools unable to employ the integrated method in performing their tasks. It seems that, most of the teachers had not clearly understanding the concept of Integrated Curriculum and lacking of model method from Ministry of Education.

\section{THE MALAY MUSLIM COMMUNITY'S REACTION TO THE EDUCATION POLICY OF THE GOVERNMENT}

Although some Muslim scholars especially those who came from the College of Islamic Studies, Prince of Songkla University apprehended that, the government is obliged to review all the Islamic Studies curricula implemented in government schools as well as to open up new channels for the running of complete Islamic Studies programs in government schools in order to sustain the population of Muslim students in this region who are rapidly moving to the Islamic private schools (Narongraksakhet 2009). In fact, the main area of contention would appear to be not over the issue of the inclusion of "secular" subjects in Islamic education but who has control over the running of the Islamic studies programs. However, Muslim communities' leaders take another interesting view. According to them, for the time being, it means that this new program is not only running by Islamic private school but government has also infiltrated to play an important role in shaping the program through implementation into government schools. The Department of Local Administration in Pattani, Yala and Narathiwat implemented this complete integration program by transferring TADIKA (Islamic preparation course or kindergarten) from Muslim communities, which was formerly based and attached to local mosques and funded by the community budget, to the government primary school. With a complete Islamic studies syllabus and integrated curriculum from Ministry of Education, will gradually transfer as well as take over Islamic studies programs running by former TADIKA and Islamic private schools. With a high standard salary, Muslim religious teacher (ustaz) will turn to government schools to teach Islamic Studies. The Government hopes that with the qualified selected Islamic religious teachers from their communities, the separatist or any deviated ideology could be soon gotten rid of. (Section of Educational Standard, Department of Local Administration 2005, 7)

Moreover, they claim that the implementation of the complex Islamic educational program seems to be the latest trend of the Thai government endeavor through educational approach of reconciliation the extreme conflicts which emerged from the basic fact of cross-cultural and religious issues. If it so, the government has to realize the fact that religious and culture i.e. Islam and Malay, are likely to be the most signification notions actually claimed by the groups involved in the unrest in terms of 
eliminating their identity and ethnicity. They actually insist that Thai authorities are hampering, if not directly eliminating, any real hope for a revival of the might of the Malay Muslim people who want to bring back their inheritance rights in their motherland.

Almost Muslim community who have engaged with the Islamic educational system, especially the owners of the Pondok and Islamic private schools in southern border provinces of Thailand, without hesitation claim that the new educational trend of Thai government clearly attack the authority of traditional Islamic educational system by deducting their population of students and quality teachers attracted by better conditions and salaries provided by the government. In fact, it likely for Malay Muslims that inevitably their Islamic educational system will be organized by the government which has no authority and authenticity in the sight of their religion and which they cannot totally trust and confident about the quality results that the government able to produce. Furthermore, they are apprehensive that this policy as policies of the previous government is merely emerging for the sake of political treatment for the Malay Muslim in southern Thailand, and not solely for the sake of national educational development. Thus, the result of running this program must be just for the political benefit, and nothing more than that.

\section{CONCLUSION}

Looking through the signification of education of the Malay-Muslim in southern Thailand, what is interesting that, beside the two opposite view pro and contra upon running the complete Islamic Studies Integrated programs in government schools, many local education agencies such as the Office of Regional Education of Pattani, Yala and Narathiwat Provinces anticipate that, this will be a historical challenge for the Thai government in terms of changing Islamic traditional education to solve the southern border provinces crisis through the educational lens, which was decided as a peace procedure and approach.

\section{REFERENCES}

Abu Hamid, al-Ghazali. 1872, Ihya' Ulum al-Din (Revivification of Islamic Knowlegde). Bulaq ed. Cairo. (in Arabic)

A.Malek, Mohd. Zamberi. 1994. Patani Dalam Tamadun Melayu. 1st ed. Selangor : Percetakan Dewan Bahasa dan Pustaka. 1993. Umat Islam Patani Sejarah dan Politik. 1st ed. Selangor : Hizbi.

AP Associated Press 2009 . "Malaysia, Thailand Eye Education to End Insurgency". Web access : http://ap.mysinchew.com/node/25671

Bashah, Haji Abdulhalim. 1994. Raja Campa \& Dinasti Jembal dalam Patani Besar (Patani,Kelantan dan Terangganu) (The King of Campa \& Jembal Dynasty in The Great Patani, (Patani, Kelantan and Terangganu). 1st ed. Kelantan : Pustaka Reka. (in Malay)

Bhabha, M. 1997. "The Nature of Islamic Education, Insight" in Islamic Foundations for Education and Welfare, vol. 12, issue 3, no. 35, pp.1-6. Website accessed at http://wwwIFEW.cominsight/v12i03

Bin Ngah, Muhammad Nor. 1983. Kitab Jawi : Islamic Thought of the Malay Muslim Scholars, Singapore : Institute of Southeast Asia Studies. 
Che Daud, Ismail. 1992. Tokoh-tokoh 'Ulama'a Semenanjung Melayu (1) (The Famous Scholars of the Malay Peninsular) (1). Kelantan : Majlis Ugama Islam dan Adat Istiadat Melayu Kelantan.

Che Man,Wan Kadir. 1983. "The Muslim Elites and Politics in Southern Thailand". M.A. thesis, University Sains Malaysia.

. 2002. "Democratization and National Integration: The Case of Thailand and Malay Muslim Community". Paper presented at the ASEAN Talk. August 31. Center for Thai Postgraduate Students IIUM (CTPS). Law building, International Islamic University Malaysia.

Dulyakasem, Uthai. 1991, "Education and Ethnic Nationalism: The Case of the MuslimMalays in Southern Thailand" in Reshaping Local Worlds : Formal Education and Cultural Change in Rural Southeast Asia, edited by Charles Keyes, pp. 131152. New Haven, Conneticut: Yale University Southeast Asia Studies.

Education Region II (Yala). 1991. Education Statistics: Private Islamic Religious Schools. Yala : Education Region II. (in Thai)

Fathi, Ahmad. 2001 a. Pengantar Sejarah Patani (Introduction to History of Patani). Kelantan : Pustaka Aman. (In Malay)

2001 b. Ulama Besar dari Fatani (The Great Scholars from Fatani). 1st ed. Selangor: University Kebangsaan Malaysia. (in Malay)

Isaac Kfir. 2007. "Southern Thailand and Islamic Terrorism". ICT (International Institute for Terrorism). Web access

http://www.ict.org.il/newsCommentaries/Commentaries/tabid/69/Articlsid/144

Jane's Intelligence Review. "Southern Thailand Insurgency Gains Fresh Momentum", vol. 16, no. 8, August 2004 (p.14).

. "School System Forms the Frontline in Thailand's Southern Unrest". vol. 16, no. 11, November 2004 (p.10).

Haji Abdullah, Abdul Rahman. 1990. Pemikiran Umat Islam di Nusantara : Sejarah Perkembangannya Hingga Abad ke-19 (Islamic Thought in Nusantara : History and Development until 19th Century). Kuala Lumpur: Dewan Bahasa dan Pustaka. (in Malay)

Koro Suzuki, "The Development and Challenges of Islamic Education in Southern Border Provinces of Thailand". Organize by Ryoko NISHII. Tokyo University of Foreign Studies.Website access on June 23, 2009: www.thaiconference.tu.ac.th/1011abstracts

Liow, Joseph. 2004, "The Pondok Schools of Southern Thailand: Bastion of Islamic Education or Hotbed of Military". Institute of Defense and Strategic Studies, NTU, Singpore. Web access : http://www.idss.edu.sg .2009, Islam, Education \& Reform in Southern Thailand: Tradition \&Transformation.1st ed. Singapore.

Madmarn, Hasan. 2000. "History of Islamic Studies in Thailand: Muslim Education Reform in Thailand - The Case of Traditional Muslim Institutions (Pondok) and its Challenges". Paper presented at international seminar: Islamic Studies in ASEAN. Pattani, Thailand.

. 2002. Pondok dan Madrasah di Patani (Pondok and Madrasah in Patani). Bangi : University Kebangsaan Malaysia. (in Malay)

Mansoer, Mohd. Dahlan. 1979. Pengantar Sejarah Nusantara Awal (Introduction to Early History of Nusantara). Kuala Lumpur : Dewan Bahasa dan Pustaka.

Ministry of Foreign Affairs Kingdom of Thailand. 2006. "Education Development". Sri Ayudhya Road, Bangkok. Website access at: www.thai2arab.com/eng/content.php?page. 
Narongraksakhet, Ibrahim. 2009. "Islamic Educational Institution in Southern Thailand". Islamic Education's Site. Web access: http://albasra1.multiply.com/journal/item/5.

Perayot Rahimmula 2002. The Role of Ulama and Islamic Education in Patani Since 1785-1945. Pattani Prince of Songkhla University (In Thai)

Pitsuwan, Surin. 1985. Islam and Malay Nationalism: A Case Study of the Malay Muslims of Southern Thailand, Bangkok: Thai Khadi Research Institute, Thammasat University.

Rung Kewdeng 1968. "The Attitude of Tok Guru upon Transforming Pondok to Islamic Private School" M.A. in Public Administration Thesis, Faculty of Public Administration, NIDA. Bangkok. (in Thai)

Section of Educational Standard, Department of Local Administration. 2005. Guideline for Implementation of Islamic Studies Program in Department of Local Administration Government School. Bangkok. (in Thai)

Sarakadee Journal. "Pondok: School of Islamic Virture", vol. 223, September 2003. Web access: http://www.sarakadee.com/feature/2003/09pondok_en.htm

S.P. Harish. 2006. "Ethnic or Religious Cleavage ? Investigating the Nature of the Conflict in Southern Thailand". In Contemporary Southeast Asian, vol. 28, no.1 (2006), pp 48-69)

Suthep Sunthorn Phesat. "Ponoh (Pondok): The Integration of Religion, Social of the Malay-Muslim in Southern Thailand". (in Thai). Web access on August 1, 2004. : http://www.skyd.org/html-social PONDOK-heritage. html

Syed Idrus, Syed Muhammad Dawilah, 1992. "The Role of Kitab Jawi in the Development of Islamic Thought in the Malay Archipelago with Special Reference to Umm al-Barahin and the Writings on the Twenty Attributes". PhD Thesis. Edinburgh : The University of Edinburgh.

Syukri, Ibrahim. 2002. Sejarah Kerajaan Melayu Patani (History of Patani Sultanate). Bangi : University Kebangsaan Malaysia. (in Malay)

Western Resistance. July 2006. "Thailand: Death Toll Rises in Muslim South". Web access : www. westernresistance. com/blog/archives $/ 002577$

Yala Islamic College. 2005. Yala Islamic College News. Year 9, vol. 36, April-June. (in Thai)

Yusuf, Imtiyaz. 2000. Islamic Studies in ASEAN. Pattani : College of Islamic Studies, Prince of Songkhla University, Thailand. 